\title{
Pengaruh Penambahan Aditif Pakan Berupa Kulit Singkong dan Bakteri Asam Laktat terhadap Pemanfaatan Protein Ransum Ayam Broiler
}

\author{
The Effect of Addition Feed Additive of Cassava Peels and Lactic Acid Bacteria in the Ration \\ on Protein Utilization of Broiler
}

\author{
S. A. Putri, E. Suprijatna dan L. D. Mahfudz
}

Departemen Peternakan, Fakultas Peternakan dan Pertanian Universitas Diponegoro, Semarang Corresponding email : sylviaarsita@gmail.com

\begin{abstract}
This research was aimed to determine the effect of addition of feed additives of cassava peel and lactic acid bacteria in the ration on protein utilization of broiler chicken. The material used in this study was 144 broiler chickens 10 days old, unsexed, with an average weight of $198.59 \pm 5.82 \mathrm{~g}$. Feed rations provided contained $18.9 \%$ protein and 3,044.9 Kcal of metabolizable energy. This research used a completely randomized design (CRD), 4 treatments and 6 replications, each experiment unit was filled with 6 chickens. The treatments applied were feed additives as follows T0: basal ration; T1: basal ration $+50 \mathrm{ml} / \mathrm{kg}$; T2: basal ration $+100 \mathrm{ml} / \mathrm{kg}$; T3: basal ration $+150 \mathrm{ml} / \mathrm{kg}$. The parameters observed included protein consumption, protein digestibility, nitrogen retention and protein mass of meat. The research data were analyzed by variance with the $F$ test, followed by Duncan's test at a probability of 5\%. The results showed that the addition of feed additives had no significant effect $(\mathrm{P}>0.05)$ on protein consumption, protein digestibility, nitrogen retention, and lean protein mass. The conclusion of this research is the addition of feed additives in the form of cassava peel and lactic acid bacteria up to $150 \mathrm{ml} / \mathrm{kg}$ of feed have not been able to increase the diet on protein utilization of broiler.
\end{abstract}

Key words: broilers, feed additives, cassava peel, lactic acid bacteria, protein utilization.

\begin{abstract}
ABSTRAK
Penelitian ini bertujuan untuk mengkaji pengaruh penambahan aditif pakan berupa kulit singkong dan bakteri asam laktat terhadap pemanfaatan protein ransum ayam broiler. Materi yang digunakan dalam penelitian ini 144 ekor ayam broiler umur 10 hari unsexed dengan bobot rata-rata 198,59 $\pm 5,82$ g. Ransum yang diberikan mengandung protein $18,9 \%$ dan energi metabolis 3.044,9 Kkal. Penelitian ini menggunakan rancangan acak lengkap (RAL), 4 perlakuan dan 6 ulangan, setiap unit percobaan diisi 6 ekor ayam. Perlakuan yang diterapkan adalah aditif pakan sebagai berikut T0: ransum basal; T1: ransum basal $+50 \mathrm{ml} / \mathrm{kg}$; $\mathrm{T} 2$ : ransum basal +100 $\mathrm{ml} / \mathrm{kg}$; T3: ransum basal $+150 \mathrm{ml} / \mathrm{kg}$. Parameter yang diamati meliputi konsumsi protein, kecernaan protein, retensi nitrogen dan massa protein daging. Data hasil penelitian dianalisis ragam dengan uji $\mathrm{F}$ dilanjutkan uji Duncan pada probabilitas 5\%. Hasil penelitian menunjukkan bahwa penambahan aditif pakan tidak berpengaruh nyata $(\mathrm{P}>0,05)$ terhadap konsumsi protein, kecernaan protein, retensi nitrogen dan massa protein daging. Kesimpulan dari penelitian ini adalah penambahan aditif pakan berupa kulit singkong dan bakteri asam laktat s/d $150 \mathrm{ml} / \mathrm{kg}$ pakan belum mampu meningkatkan pemanfaatan protein ransum ayam broiler.
\end{abstract}

Kata Kunci : broiler, aditif pakan, kulit singkong, bakteri asam laktat, pemanfaatan protein.

\section{PENDAHULUAN}

Ayam broiler atau ayam pedaging merupakan ayam yang memiliki pertumbuhan yang sangat cepat dan daya produktivitas yang tinggi dalam memproduksi daging, selain itu juga terdapat kelemahan yaitu daya tahan tubuh rendah. Kini banyak peternak yang ayam broiler yang menggunakan antibiotik untuk mengatasi daya tahan tersebut, namun penggunaan antibiotik kini sudah dilarang karena dapat menghasilkan residu pada produknya sehingga akan membahayakan konsumen. Oleh karena itu perlu dicari alternatif lain sebagai pengganti penggunaan antibiotik yang tidak meinggalkan efek negatif.

Dewasa ini banyak dikembangkan alternatif pengganti antibiotik yaitu dengan pemberian aditif pakan berupa prebiotik, probiotik maupun sinbiotik. Probiotik merupakan produk yang mengandung mikroba atau bakteri nonpatogen yang dapat hidup di usus sebagai pakan imbuhan yang menguntungkan inangnya, sedangkan prebiotik merupakan sumber energi atau nutrien bagi mikroba dalam meningkatkan populasi mikroba yang menguntungkan pada 
saluran pencernaan (Haryati, 2011). Prebiotik yang digunakan berupa kulit singkong karena terdapat kandungan oligosakarida berupa inulin $0,12 \%$, maltopentosa $0,003 \%$, rafinosa $0,06 \%$, mannosa $1,99 \%$, sukrosa $1,39 \%$, arabinosa $0,01 \%$ dan glukosa $1,84 \%$ (Laboratorium Balai Penelitian Ternak, 2018) dan probiotik berupa bakteri asam laktat. Kandungan oligosakarida akan dimanfaatkan oleh bakteri menguntungkan atau bakteri asam laktat yang hidup di dalam saluran pencernaan sebagai sumber nutrien (Haryati dan Supriyati, 2010).

Pemberian kulit singkong sebagai nutrien bakteri asam laktat dapat meningkatkan populasi BAL dan produksi asam laktat sehingga $\mathrm{pH}$ menurun serta menghasilkan bakteriosin yang dapat menekan populasi bakteri patogen. Kondisi tersebut juga meningkatkan aktivitas enzimenzim pencernaan seperti enzim protease dan saluran pencernaan lebih sehat, sehingga proses pencernaan maupun penyerapan nutrien ransum menjadi meningkat, terutama protein. Diharapkan dapat meningkatkan kecernaan protein dan pemanfaatan protein ransum juga meningkat (Widodo et al., 2015).

Tujuan dari penelitian ini yaitu untuk mengevaluasi pengaruh aditif pakan terhadap pemanfaatan protein ransum ayam broiler yang dapat ditinjau dari nilai konsumsi protein, kecernaan protein, retensi nitrogen dan massa protein daging. Hasil penelitian memberikan informasi tentang penambahan aditif pakan berupa kulit singkong dan BAL terhadap pemanfaatan protein ransum ayam broiler

\section{MATERI DAN METODE}

Materi yang digunakan dalam penelitian ini 144 ayam broiler umur 10 hari unsexed dengan bobot badan 198,59 $\pm 5,82$ g. Ayam dipelihara pada kandang litter, saat total koleksi menggunakan kandang baterai. Ransum yang digunakan mengandung protein $18,9 \%$ dan energi metabolis 3.044,9 Kkal. Bahan pakan untuk menyusun ransum terdiri dari jagung, bekatul, bungkil kedelai, tepung ikan, Meat Bone Meal (MBM), premix dan $\mathrm{CaCO}_{3}$. Aditif pakan yang digunakan yaitu kulit singkong yang diperoleh dari pabrik Singkong Keju D-9 Salatiga dan isolat bakteri bakteri asam laktat dari Universitas Muhammadiyah Semarang. Komposisi dan kandungan nutrisi ransum penelitian disajikan pada Tabel 1.

Pembuatan aditif pakan dimulai dengan pembuatan prebiotik tepung kulit singkong dengan cara kulit singkong dipisahkan dari kulit arinya, cuci hingga bersih, kulit singkong dipotong-potong kecil, dijemur hingga kering dibawah sinar matahari, kemudian kulit singkong yang sudah kering di

Tabel 1. Komposisi dan kandungan nutrisi ransum penelitian ayam broiler

\begin{tabular}{lrr}
\hline Komposisi Bahan Pakan & Starter & Finisher \\
\hline Jagung & 45,55 & 50,00 \\
Bekatul & 15,65 & 20,00 \\
Tepung Ikan & 7,00 & 7,00 \\
Bungkil Kedelai & 25,80 & 17,00 \\
MBM & 3,00 & 3,00 \\
Premix & 1,00 & 1,00 \\
CaCO & 2,00 & 2,00 \\
Total & 100 & 100 \\
\hline Kandungan Nutrisi dalam ransum & & \\
\hline Energi Metabolis (Kkal)** & 3029,19 & $3.048,86$ \\
Protein Kasar (\%)* & 22,27 & 18,99 \\
Lemak Kasar (\%)* & 6,69 & 7,37 \\
Serat Kasar (\%)* & 7,11 & 7,60 \\
Kalsium (\%)* & 1,51 & 1,47 \\
Phospor (\%)* & 0,72 & 0,75 \\
\hline
\end{tabular}

*Analisis proksimat dilakukan di Laboratorium Nutrisi dan Pakan, Fakultas Peternakan dan Pertanian, Universitas Diponegoro, Semarang.

**Berdasarkan rumus perhitungan dengan rumus Balton (Siswohardjono, 1982): EM (kkal/kg) $=40,81$ [ 0,87 $(\mathrm{PK}+2,25 \mathrm{x} \mathrm{LK}+\mathrm{BETN}+\mathrm{k})]$ 
giling hingga menjadi tepung. Pembuatan probiotik dilakukan dengan cara mengisolasi bakteri asam laktat dari saluran pencernaan itik bagian sekum. Selanjutnya dilakukan inkubasi dan kulturisasi selama 24 jam untuk mendapatkan indukan bakteri asam laktat dengan jumlah $2,3 \times 10^{8} \quad \mathrm{CFU} / \mathrm{ml}$. Tahap berikutnya dilakukan uji dosis tepung kulit singkong dan bakteri asam laktat terhadap total bakteri. Uji dosis dilakukan dengan cara mencampurkan tepung kulit singkong sebanyak $4 \%(0,4 \mathrm{~g}), 5 \%$ $(0,5 \mathrm{~g})$ dan $6 \%(0,6 \mathrm{~g})$, masing-masing dosis dicampurkan dengan bakteri asam laktat yang kemudian diinkubasi selama 24 jam dengan suhu $37^{\circ} \mathrm{C}$. Selanjutnya dilakukan pengenceran hingga memperoleh dosis kombinasi tepung kulit singkong dan bakteri asam laktat yang optimal. Dosis kombinasi yang optimal diperoleh pada kandungan kulit singkong 6\% dengan pengenceran $10^{8}$ yaitu dengan total bakteri $6,5 \times 10^{9} \mathrm{CFU} / \mathrm{ml}$.

Rancangan percobaan yang digunakan adalah rancangan acak lengkap (RAL) dengan 4 perlakuan dan 6 ulangan sehingga terdapat 24 unit percobaan, setiap unit percobaan terdiri dari
6 ekor ayam broiler. Perlakuan aditif pakan berupa kombinasi kulit singkong dan BAL sebagai berikut :

T0 : Pemberian ransum basal (kontrol)

T1 : Pemberian ransum basal + aditif pakan $50 \mathrm{ml} / \mathrm{kg}$ ransum

T2 : Pemberian ransum basal + aditif pakan $100 \mathrm{ml} / \mathrm{kg}$ ransum

T3 : Pemberian ransum basal + aditif pakan $150 \mathrm{ml} / \mathrm{kg}$ ransum

Ransum perlakuan diberikan pada ayam mulai umur 10 hari s/d umur 38 hari. Aditif pakan diberikan dengan cara dicampur secara homogen pada ransum sebanyak 20\% dari kebutuhan dan diberikan pada pagi hari.

Parameter yang diamati dalam penelitian ini adalah konsumsi protein, kecernaan protein, retensi nitrogen dan massa protein daging. Selama tahap perlakuan dilakukan pencatatan konsumsi ransum untuk mengetahui data konsumsi ransum guna menghitung konsumsi protein. Konsumsi protein dihitung berdasarkan rumus Tillman et al. (1991) :

\section{- Konsumsi protein $(g)=$ konsumsi ransum $(g) x$ kadar protein kasar ransum (\%)}

Pengambilan data kecernaan dan retensi nitrogen dilakukan total koleksi menggunakan satu ekor ayam dari setiap unit percobaan hingga memperoleh 24 ekor ayam. Total koleksi dengan menggunakan indikator $\mathrm{Fe}_{2} \mathrm{O}_{3}$ yang dilakukan selama 4 hari pada akhir pemeliharaan. Hari pertama dimulai dengan pemuasaan 24 jam. Hari kedua ayam diberi ransum dengan tanpa indikator dan ditampung ekskretanya. Hari ketiga ayam diberi ransum dengan indikator dan ditampung lagi ekskretanya dengan penampung sudah diganti. Hari keempat ayam diberi ransum tanpa indikator dan ditampung lagi ekskretanya dengan penampung sudah diganti. Penampungan eksreta dilakukan pada hari kedua sampai hari keempat. Ekskreta yang telah ditampung kemudian ditimbang dan disemprot dengan $\mathrm{HCl}$ secara berkala untuk mencegah penguapan $\mathrm{N}$. Ekskreta yang telah ditampung kemudian dijemur dibawah sinar matahari hingga kering selama 3 hari, setelah kering ekskreta ditimbang kembali. Terakhir ekskreta dianalisis kandungan protein kasar untuk dapat mengetahui kandungan nitrogennya. Kecernaan protein, dihitung menggunakan rumus Sibbald dan Wolynetz (1984) yaitu :

Kecernaan protein $(\%)=\frac{\text { konsumsi protein }- \text { protein eksreta }}{\text { konsumsi protein }} \times 100 \%$

Retensi nitrogen dihitung menggunakan rumus Resnawati (2006) yaitu :

Retensi nitrogen $(\mathrm{g})$ = konsumsi nitrogen $(\mathrm{g})$ - nitrogen ekskreta $(\mathrm{g})$

Pengambilan data massa protein daging, dengan cara menganalisis kadar protein daging yang diambil dari campuran daging paha dan dada yang telah dihaluskan sebanyak $30 \mathrm{~g}$. Kadar protein daging dianalisis dengan metode Kjeldhal-mikro. Massa protein daging dihitung dengan rumus Suthama (2003)

Massa protein daging $(\mathrm{g})=$ kadar protein daging $(\%)$ x bobot daging 
Analisis Data

Data hasil penelitian selanjutnya diolah secara statistik dengan analisis ragam menggunakan uji $\mathrm{F}$ untuk mengetahuai pengaruh perlakuan pada taraf 5\%. Apabila terdapat pengaruh perlakuan yang nyata maka dilanjutkan dengan uji Duncan untuk mengetahui perbedaan antar perlakuan. Analisis data dibantu dengan program SAS versi 9.1.

\section{HASIL DAN PEMBAHASAN}

Hasil penelitian pengaruh penambahan kulit singkong dan bakteri asam laktat sebagai aditif pakan terhadap pemanfaatan protein ransum ayam broiler tertera pada Tabel 2 dan Tabel 3.

\section{Konsumsi Protein}

Berdasarkan hasil analisis statistik, penambahan aditif pakan tidak berpengaruh nyata $(\mathrm{P}>0,05)$ terhadap konsumsi protein ayam broiler. Nilai konsumsi protein pada penelitian ini antara 488,05-519,93 g/ekor. Hasil tersebut sesuai dengan penelitian Sejati et al. (2017) mengenai penggunaan tepung limbah pertanian umbi wortel yang menunjukan hasil konsumsi protein selama pemeliharaan sebesar 518,81532,77 g/ekor. Pemberian perlakuan yang belum mampu meningkatkan konsumsi protein kemungkinan aditif pakan yang diberikan masih memiliki kandungan $\mathrm{HCN}$ sebesar 38,2 ppm. Menurut Agustiningsih (2002) bahwa HCN yang terkonsumsi secara langsung akan didetoksifikasi dengan cara mengikat sulfur dari asam-asam amino sehingga dapat menurunkan kualitas asam amino dan mempengaruhi nilai konsumsi, kecernaan maupun performans ternak.

Konsumsi protein yang tidak berbeda nyata antar perlakuan disebabkan oleh konsumsi ransum yang menunjukan tidak berbeda dengan rata-rata 2.598,93 g/ekor. Konsumsi ransum yang tidak berbeda dipengaruhi karena ransum yang diberikan pada tiap perlakuan mengandung nilai nutrien yang sama, khususnya energi metabolis dan protein. Kandungan EM ransum yang diberikan pada setiap perlakuan memiliki nilai yang sama yaitu $3.048,86 \mathrm{kkal} / \mathrm{kg}$ sehingga konsumsi ransum juga tidak berbeda, hal ini dikarenakan ayam akan mengkonsumsi ransum berdasarkan kebutuhan EM. Maghfiroh et al. (2012) menyatakan bahwa kandungan energi dalam ransum dapat mempengaruhi jumlah konsumsi ransum. Wahju (2004) menyatakan bahwa ransum yang mengandung energi tinggi akan menyebabkan turunnya jumlah konsumsi ransum, dan sebaliknya. Sama halnya dengan pemberian ransum dengan kandungan protein yang sama maka jumlah protein yang terkonsumsi juga sama. Hal ini sesuai pendapat Khodijah et al. (2012) yang menyatakan bahwa tinggi rendahnya protein yang dikonsumsi dipengaruhi oleh kadar protein yang terkandung ransum serta jumlah ransum terkonsumsi, dimana konsumsi ransum dan kadar protein ransum yang tinggi maka akan menghasilkan jumlah konsumsi protein yang semakin tinggi pula.

\section{Kecernaan Protein}

Penambahan aditif pakan tidak memberikan pengaruh nyata $(\mathrm{P}>0,05)$ terhadap kecernaan protein protein. Nilai kecernaan protein yang diperoleh yaitu antara 84,39 $87,34 \%$. Nilai kecernaan protein tersebut tergolong tinggi, namun masih berada dalam kisaran normal. Hal ini sesuai pendapat Anggorodi (1994) bahwa nilai kecernan dapat dikelompokkan menjadi 3 kategori, yaitu kecernaan dikatakan rendah apabila berada dalam kisaran $50-60 \%$, kualias sedang berkisar 60 $70 \%$ dan bekualitas tinggi jika lebih dari $70 \%$.

Kecernaan protein yang tidak berbeda nyata pada setiap perlakuan diduga karena nilai konsumsi protein yang menunjukan tidak berbeda. Selain itu adanya kandungan $\mathrm{HCN}$ sebesar 38,2 ppm, walaupun nilai $\mathrm{HCN}$ tersebut masih dapat ditoleransi ternak. Hal ini sesuai pendapat Sudiyono (2010) bahwa HCN yang kurang dari50 ppm masih aman dikonsumsi dan tidak berbahaya. Meskipun kandungan $\mathrm{HCN}$ aman dikonsumsi kemungkinan menyebabkan BAL kurang berkembang, sehingga penambahan

Tabel 2. Pengaruh perlakuan terhadap pemanfaatan protein ransum ayam broiler

\begin{tabular}{lcccc}
\hline \multirow{2}{*}{\multicolumn{1}{c}{ Variabel }} & \multicolumn{4}{c}{ Perlakuan } \\
\cline { 2 - 5 } & T0 & T1 & T2 & T3 \\
\hline Konsumsi protein $(\mathrm{g})$ & $518,93 \pm 25,09$ & $508,35 \pm 40,19$ & $488,97 \pm 55,28$ & $488,05 \pm 23,55$ \\
Kecernaan protein $(\%)$ & $84,39 \pm 5,07$ & $87,34 \pm 3,49$ & $87,24 \pm 2,99$ & $87,08 \pm 3,02$ \\
\hline
\end{tabular}

Keterangan : Rata-rata diatas menunjukan tidak ada pengaruh yang nyata $(\mathrm{P}>0,05)$ 
aditif pakan belum mampu meningkatkan populasi BAL dan produksi asam laktat.Hal ini dibuktikan dengan nilai $\mathrm{pH}$ yang sama dengan rata-rata 5,63. Menurut Akhardianto (2010) bakteri saluran pencernaan membutuhkan $\mathrm{pH}$ sekitar 4 - 6 untuk dapat berkembang biak. Nilai $\mathrm{pH}$ yang sama mengakibatkan aktivitas enzimenzim pencernaan yang diaktifkan masih sama, sehingga nilai kecernaan yang dihasilkan juga sama. Wahyuni et al. (2008) bahwa kecernaan dapat dipengaruhi oleh aktivitas enzim. Radhiyani et al. (2017) menambahkan turunnya $\mathrm{pH}$ saluran pencernaan dapat menjadikan suasana menjadi asam serta meningkatkan aktivitas enzim-enzim pencernaan yang berperan dalam mencerna protein, sehingga dapat meningkatkan kecernaan protein.

\section{Retensi Nitrogen}

Berdasarkan hasil analisis ragam menunjukan bahwa penambahan aditif pakan tidak memberikan pengaruh yang nyata $(\mathrm{P}>0,05)$ terhadap retensi nitrogen. Rata-rata nilai retensi nitrogen sebesar 3,41 - 3,73 g. Penambahan aditif pakan belum mampu meningkatkan retensi nitrogen diduga karena nilai konsumsi protein yang sama.

Berdasarkan hasil analisis ragam menunjukan bahwa penambahan aditif pakan tidak memberikan pengaruh yang nyata $(\mathrm{P}>0,05)$ terhadap retensi nitrogen. Rata-rata nilai retensi nitrogen sebesar 3,41 - 3,73 g. Penambahan aditif pakan belum mampu meningkatkan retensi nitrogen diduga karena nilai konsumsi protein yang sama.

Retensi nitrogen yang tidak berbeda nyata disebabkan karena kosumsi protein antar perlakuan juga tidak berbeda nyata, selain itu ransum yang diberikan mempunyai kandungan protein yang sama. Wahju (2004) menyatakan bahwa retensi nitrogen dapat diengaruhi oleh faktor konsumsi protein, kualitas protein dan energi metabolis. Nitrogen berhubungan erat dengan protein sehingga kecernaan protein juga akan berpengaruh terhadap nitrogen yang diretensi. Primacita et al. (2014) kandungan protein dalam ransum dapat mempengaruhi jumlah retensi nitrogen, hal ini dikarenakan nitrogen yang diretensi sesuai dengan kandungan protein dalam ransum. Saraswati et al. (2015) menambahkan bahwa tinggi rendahnya nilai konsumsi protein maupun kecernaan protein sangat mempengaruhi jumlah retensi nitrogen, dikarenakan jumlah protein yang dikonsumsi akan menentukan pemanfaatan nitrogen. Faktor lain yang dapat mempengaruhi retensi nitrogen yaitu kadar serat kasar pada ransum. Serat kasar ransum yang tinggi dapat menurunkan retensi nitrogen karena sebagian nutrisi dari ransum susah untuk dicerna termasuk protein dan ikut terbuang bersama ekskreta. Menurut Hidayat et al. (2016) kebutuhan akan serat pada ayam broiler berkisar antara $3-5 \%$. Mangisah $e t$ al. (2008) tingginya serat kasar dalam ransum akan menurunkan nilai kecernaan dan retensi nitrogen, karena serat kasar dapat menyebabkan nilai nutrisi lain pada ransum susah untuk dicerna termasuk protein sebagai sumber nitrogen.

Retensi nitrogen sejalan dengan jumlah konsumsi protein dan kecernaan protein, dengan meningkatnya jumlah konsumsi protein maka nilai kecernaan juga meningkat. Kondisi tersebut berarti juga akan meningkatkan nilai retensi nitrogen karena $16 \%$ dari protein merupakan nitrogen. Berdasarkan nilai rata-rata menunjukan bahwa nilai retensi nitrogen positif, artinya jumlah nitrogen yang dikonsumsi lebih banyak dibandingkan dengan nitrogen yang dikeluarkan melalui ekskreta. Maghfiroh et al. (2009) apabila jumlah nitrogen yang keluar melalui ekskreta lebih rendah dari nitrogen dikonsumsi maka dapat dikatakann nilai retensi tersebut positif.

Tabel 3. Pengaruh perlakuan terhadap retensi protein ransum dan massa protein daging ayam broiler

\begin{tabular}{lcccc}
\hline \multirow{2}{*}{\multicolumn{1}{c}{ Variabel }} & \multicolumn{4}{c}{ Perlakuan } \\
\cline { 2 - 5 } & $\mathrm{T} 0$ & $\mathrm{~T} 1$ & $\mathrm{~T} 2$ & $\mathrm{~T} 3$ \\
\hline Retensi nitrogen $(\mathrm{g})$ & $3,41 \pm 0,41$ & $3,73 \pm 0,13$ & $3,61 \pm 0,26$ & $3,69 \pm 0,12$ \\
Massa protein daging $(\mathrm{g})$ & $50,22 \pm 2,89$ & $52,83 \pm 4,47$ & $52,52 \pm 4,17$ & $48,32 \pm 2,76$ \\
\hline
\end{tabular}

Keterangan : Rata-rata diatas menunjukan tidak ada pengaruh yang nyata $(\mathrm{P}>0,05)$ 


\section{Massa Protein Daging}

Penambahan aditif pakan tidak berpengaruh nyata $(\mathrm{P}>0,05)$ terhadap massa protein daging. Rataan nilai massa protein daging penelitian ini berkisar antara 48,32 - 52,83 g. Massa potein daging pada penelitian ini dapat dikatakan sangat rendah jika dibandingkan dengan Mirnawati et al. (2013) yang melaporkan bahwa massa protein daging yang dihasilkan sebesar 109,99 g. Perbedaan hasil tersebut dipengaruhi oleh kualitas protein, kecernaan protein. Sari et al. (2014) faktor yang dapat mempengaruhi massa protein daging yaitu jumlah protein yang dikonsumsi, daya cerna serta sintesi protein

Massa protein daging yang tidak berbeda nyata antar perlakuan selaras dengan bobot badan akhir ayam broiler dengan rata-rata 939,76 g. Radhiyani et al. (2017) tingginya massa protein daging semakin besar konstribusinya terhadap pertambahan bobot badan hingga menghasilkan bobot badan akhir yang tinggi pula. Massa protein daging yang rendah disebabkan oleh nilai konsumsi dan kecernaan protein yang rendah pula, sehingga asupan yang dihasilkan juga rendah akibatnya tidak dapat mampu meningkatkan pertambahan bobot badan. Saputra et al. (2016) meningkatnya kecernaan protein dapat mempengaruhi nilai massa protein daging karena asupan protein merupakan substrat untuk berlangsungnya proses sintesis protein. Massa protein daging yang rendah mengakibatkan produksi daging juga rendah. Hal ini dipengaruhi oleh kandungan protein ransum yang dapat menjadikan kecernaan protein yang tidak berbeda sehingga menyebabkan protein yang dikonsumsi juga sama. Menurut Sari et al. (2014) rendahnya kandungan protein dalam ransum akan menghasilkan kandungan protein daging juga rendah sehingga massa protein daging yang dihasilkan juga rendah. Semakin tinggi nilai massa protein daging maka menunjukan bahwa kualitas daging semakin baik.

\section{KESIMPULAN}

Hasil penelitain ini dapat disimpulkan bahwa penambahan aditif pakan s/d $150 \mathrm{ml} / \mathrm{kg}$ belum mampu memperbaiki atau meningkatkan pemanfaatan protein ransum dilihat dari konsumsi protein, retensi nitrogen, kecernaan protein dan massa protein daging.

\section{SARAN}

Perlu adanya penelitian lebih lanjut mengenai aditif pakan berupa prebiotik kuli singkong dan probiotik bakeri asam laktat supaya mendapatkan hasil yang optimal untuk meningkatkan pemanfaatan protein ransum ayam broiler.

\section{DAFTAR PUSTAKA}

Agustiningsih, D. 2002. Pegaruh Penggunaan Bungkil Biji Karet Fermentasi dengan Inokulum Tempe dan Oncom Dalam Ransum terhadap Perormans Ayam Pedaging. Fakultas Peternakan Universitas Diponegoro, Semarang. (Tesis).

Anggorodi, R. 1994. Nutrisi Aneka Ternak Unggas. PT Gramedia Pustaka Utama, Jakarta.

Haryati, T dan Supriyati. 2010. Pemanfaatan senyawa oligosakarida dari bungkil kedelai dan ubi jalar pada ransum ayam pedaging. J. Ilmu Ternak dan Veteriner. 15 (4): 253-260.

Haryati, T. 2011. Probiotik dan prebiotik sebagai pakan imbuhan nonruminansia. Wartazoa. 21 (3): 125-132.

Hidayat, M. N., R. Malaka., L. Agustina dan W. Pakiding. 2018. Effect of Lactobacillus sp. probiotics on intestinal histology, Escherichia coli in excreta and broiler performance. JITAA. 43 (4): 445-452.

Khodijah, E., S., Abun dan R. Wiradimadja. 2012. Imbangan efisiensi protein broiler yang diberi ransum mengandung ekstrak kulit jengkol (Pithecellobium jiringa (Jack) Prain). Students e-Journal. 1 (1): 14-19.

Laboratorium Balai Penelitian Ternak, 2018. Hasil Analisis Oligosakarida Kulit Singkong. LP / 23 / IX - 2018, Bogor.

Magfiroh, K., I. Mangisah dan V. D. Y. B. Ismadi. 2012. Pengaruh penambahan sari jeruk nipis (Citrus aurantifolia) dalam ransum terhadap kecernaan protein kasar 
dan retensi nitrogen pada itik magelang jantan. Anim. Agric. J. 1 (1) : 669-683.

Mangisah, I., N. Suthama, V. D. Yunianto dan D. Hastuti. 2008. Pengaruh berbagai serat kasar dalam ransum terhadap retensi nitrogen dan massa protein daging. Buletin Peternakan 32 (2): 78-84.

Mirnawati, B. Sukamto, dan V. D. Yunianto. 2013. Kecernaan protein, retensi nitrogen dan massa protein Daging ayam broiler yang diberi ransum daun murbei (Morus alba l.) yang difermentasi dengan cairan rumen. JITP. 3 (1): 25-32.

Primacitra, D. Y., Osfar Sjofjan dan M. H. Natsir. 2014. Pengaruh penambahan probiotik (Lactobacillus sp.) dalam pakan terhadap energi metabolis, kecernaan protein dan aktivitas enzim burung puyuh. J. Ternak Tropika 15 (1): 74-79.

Radhiyani, U. A., N. Suthama dan I. Mangisah. 2017. Pengaruh penambahan asam asetat pada ransum dengan level protein berbeda terhadap retensi kalsium dan massa protein daging pada ayam broiler. Agromedia 3 (1) : 21-27.

Resnawati, H. 2006. Retensi nitrogen dan energi metabolis ransum yang mengandung cacing tanah (Lumbricus rubellus) pada ayam pedaging. J. Ilmu Ternak dan Veteriner 19 (3): 663-667.

Saputra, Y., N. Suthama dan B. Sukamto. 2016. Suplementation of purple sweet potato extract on protein digestibility and meat protein mass in broiler reared under different cage density. Proceedings of International Seminar on Livestock Production and Veterinary Technology 378-384.

Saraswati, A., N. Suthama dan V. D. Y. B. Ismadi. 2015. Penggunaan protein akibat pemberian porsi ransum berbeda dikombinasikan dengan lama pencahayaan pada ayam broiler. Anim. Agric. J. 4 (1): 182-189.

Sari, K. A., B. Sukamto dan B. Dwiloka. 2014. Efisiensi penggunaan protein pada ayam broiler dengan pemberian pakan mengandung tepung daun kayambang (Salvinia molesta). J. Agripet. 14 (2): 7683.

Sejati, P., L. D. Mahfudz dan V. D. Yunianto. 2017. Pengaruh penggunaan tepung limbah pertanian umbi wortel (Daucus carrota. L) dalam ransum terhadap kecernaan protein pada ayam broiler. J. Ilmu-ilmu Pertanian 13 (2) : 22-32.

Sibbald, I. R. dan M. S. Wolynetz. 1984. Relationship between apparent and true metabolizable energy and the effect of nitrogen correction. J. Poult. Sci. 63: $1386-1399$.

Sudiyono. 2010. Penggunaan Na2hco3 untuk Mengurangi Kandungan Asam Sianida (HCN) Koro Benguk pada Pembuatan Koro Benguk Goreng. J. Ilmu-Ilmu Pertanian 4 (1): 48-53.

Suthama, N. 2003. Metabolisme protein pada ayam kampung periode pertumbuhan yang diberi ransum memakai dedak padi fermentasi. J. Pengemb. Pet. Trop. Edisi Spesial, hal 44-48.

Tillman, A. D., H. Hartadi, S. Reksohadiprodjo, S. Prawirokusumo, dan S. Lebdosoekojo. 1991. Ilmu Makanan Ternak Dasar. Cetakan kelima. Gadjah Mada University Press, Yogyakarta.

Wahju, J. 2004. Ilmu Nutrisi Unggas. Edisi 4. Gadjah Mada University Press, Yogyakarta.

Wahyuni, H. I., R. I. Pujaningsih dan P. A. Sayekti. 2008. Kajian energi metabolis biji sorghum melalui teknologi sangria pada ayam petelur periode afkir. Agripet. 8

(1): 25-30.

Widodo, T. S., B. Sulistiyanto dan C. S. Utama. 2015. Jumlah bakteri asam laktat (BAL) dalam digesta usus halus dan sekum ayam broiler yang diberi pakan ceceran pabrik pakan yang difermentasi. Agripet. 15 (2): $98-103$ 